\title{
Religión, etnia y sociedad: cofradías de negros en el Panamá colonial
}

\author{
Carmen Mena García \\ Departamento de Historia de América \\ Universidad de Sevilla
}

\begin{abstract}
En el presente trabajo se analiza una de las manifestaciones religiosas de mayor arraigo en la América colonial de habla española: el de las cofradías, si bien nos centramos en un grupo étnico, el de los negros, y en una región que desde fechas muy tempranas da cabida a una abundante población de color, como es la región centroamericana de Panamá. Las cofradías de negros, a las que, por desgracia, no se ha prestado demasiada atención hasta la fecha, constituyen un interesantísimo fenómeno religioso y social, digno de ser estudiado. Como órganos de culto y a la vez instrumentos de sociabilidad étnica, muchas de ellas admitían también entre sus filas a hermanos esclavos, lo que sirvió para mantener los vínculos entre los que ya eran libres y los que todavía seguían sometidos a la esclavitud, entre los que estaban comprometidos con el sistema y los que aún tenían sobradas razones para luchar contra él. Por otro lado, las fiestas patronales fueron la excusa perfecta para expresar por medio de la danza, la música y otras manifestaciones folklóricas, combinadas con elementos rituales cristianos, la alegría, la vitalidad y el sentimiento propio de una raza y de una cultura, a menudo constreñidas en la vida diaria por los severos requerimientos de la esclavitud, produciendo interesantes fenómenos de sincretismo religioso.
\end{abstract}

\section{Las cofradías de negros como vehículos de integración religiosa y cultural}

Las cofradías son sociedades religiosas de derecho eclesiástico, que agrupan principalmente a seglares movidos por una clara finalidad espiritual y benéfico-asistencial. En ellas siempre están presentes tres objetivos: 1. Promover la celebración del culto en honor de los titulares de la Hermandad; 2. Buscar la salvación del alma mediante una serie de prácticas religiosas, algunas colectivas, como participación en misas, rosarios, festividades o procesiones, aunque también incluyen otras prácticas individuales que son premiadas con indulgencias tras el pago de la correspondiente cuota; 3. Ejercitar la caridad asistencial entre sus miembros y especialmente entre los más necesitados.

Cofradías hubo muchas y muy diversas, siendo susceptibles de ser clasificadas atendiendo a criterios muy diferentes y desde distintas perspectivas. Eso explica que no exista unanimidad por parte de los autores ni tampoco un solo arquetipo fijado y aceptado por todos. Bajo el prisma social y refiriéndose al territorio peruano, Olinda Celestino y A. Meyers estable- 
cen la siguiente tipología: 1. Cofradías aristocráticas de criollos y españoles (por ejemplo, La Veracruz en Lima); 2. Cofradías gremiales incluyendo como variantes cofradías elitistas (por ejemplo, los hidalgos plateros); 3. Cofradías vinculadas a grupos étnicos peninsulares (por ejemplo Los Vizcaínos); 4. Cofradías de socorros mutuos independientes de los gremios; 5. Cofradías culturales; 6 . Cofradías de negros; 7 . Cofradías de indios. ${ }^{1}$

Años atrás, Isidoro Moreno, en su estudio sobre las hermandades andaluzas, llegó a distinguir hasta 15 tipos teóricos o ideales, precisando que para elaborar dichos modelos había partido de tres criterios fundamentales, cuya combinación utiliza para establecer una tipología: "la forma de pertenencia, es decir el grado en que los individuos pueden elegir o no voluntariamente el pertenecer a la cofradía, lo que depende del grado real, no formal, de apertura o exclusivismo" distinguiendo así entre hermandades abiertas y cerradas; "la forma de integración de los componentes, según que éstos pertenezcan a una misma categoría social — hermandad horizontal - o a varias - hermandad vertical - y el nivel de identificación colectiva (o de integración sociocultural) que la hermandad represente y que puede ser grupal - por expresar la identidad de un gremio, etnia, clase social, sección territorial, etc. en un contexto multigrupal- semicomunal, comunal o supracomunal."2

Además de esta disparidad de criterios a la hora de diferenciar las modalidades de cofradías existentes, tanto americanas como peninsulares, existe una amplia controversia — no resuelta aún del todo- acerca de si las cofradías, y especialmente las étnicas, fueron asociaciones voluntarias o impuestas. ${ }^{3}$ Hace ya muchos años Gabriel Le Bras las definió como "Solidaridades Consentidas" haciendo hincapié en las notables diferencias existentes entre un ejercicio activo de la voluntad a través de la libre elección del sujeto y el consentimiento casi pasivo de la adscripción a una institución dada. ${ }^{4}$ Respecto a las cofradías indígenas, los estudios de Celestino y Meyers no permiten conclusiones definitivas, pero sugieren que al menos en sus ini-

1 Celestino, Olinda, y Albert Meyers: Las cofradías en el Perú: región central, Frankfurt/ Main, 1981, pág. 8 .

2 Moreno, Isidoro: "Control político, integración ideológica e identidad étnica: El 'sistema de cargos' de las comunidades indígenas americanas como adaptación de las cofradías étnicas andaluzas", Primeras Jornadas de Andalucía y América, La Rábida, Huelva, 1981, tomo II, pág. 257.

3 Un resumen de este debate hasta 1981 en Celestino y Meyers: Las cofradías en el Perú..., págs. 8-13. Interesantes reflexiones en Foster, Georges M.: "Cofradía y compadrazgo en España e Hispanoamérica", Guatemala Indígena, 1, 1961, págs.107-135.

4 Etudes de Sociologie Religieuse, París, 1956, tomo II, págs. 418 y ss. Citado por Celestino y Meyers: Las cofradías en el Perú..., pág. 9. 
cios, coincidiendo con las campañas de extirpación de idolatrías, estas asociaciones fueron instrumentadas "por el poder eclesiástico colonizador con el propósito de controlar religiosamente a los campesinos indios. De ser así, el libre albedrío del indio para pertenecer o no a la cofradía sería mínimo".

Andalucía daba cabida ya en la época del descubrimiento del Nuevo Mundo a una sociedad pluriétnica, de manera que no es cierto que fuera en América donde se plantee por primera vez al Estado castellano el problema de integrar y asimilar a una etnia dominada. Según diversos autores, desde el siglo XIV existen cofradías de negros en Sevilla y posteriormente se crean también en otras ciudades importantes: Cádiz, Jerez de la Frontera, Puerto de Santa María, respondiendo al tipo de hermandad que Moreno define como "grupal-horizontal-cerrada". ${ }^{6}$

En casi todas las ciudades importantes, a uno y otro lado del Atlántico, los negros se asociaron en cofradías $^{7}$ que, a la vez que órganos de culto, fueron instrumentos de sociabilidad étnica. Muchas admitían también a esclavos, lo que sirvió para mantener los vínculos entre los que ya eran libres y los que todavía seguían sometidos a la esclavitud, entre los que estaban comprometidos con el sistema y los que aún tenían sobradas razones para luchar contra él. Por otro lado, las fiestas patronales fueron la excusa perfecta para expresar por medio de la danza, la música y otras manifestaciones folklóricas, combinadas con elementos rituales cristianos, la alegría, la vitalidad y el sentimiento propio de una raza y de una cultura, a menudo constreñidas en la vida diaria por los severos requerimientos de la esclavitud, produciendo interesantes fenómenos de sincretismo religioso. ${ }^{8}$ Las ceremo-

5 Ibídem, pág. 11.

6 Las hermandades andaluzas. Una aproximación desde la antropología, Sevilla, 1974, y "Control político, integración...", pág. 257. Véase también: Sancho de Sopranis, Hipólito y Juan de la Lastra y Terry: Historia de Jerez de la Frontera desde su incorporación a los dominios cristianos, tomo II, El Siglo de Oro, Jerez de la Frontera, 1964, págs. 231 y ss.

7 Mulvey, Patricia Ann: The Black Lay Brotherhoods of Colonial Brazil. Brazil-New York, 1976 (tesis). En esta obra que no hemos podido, por desgracia, consultar se incluye, al parecer, una impresionante lista de las cofradías de negros que entre 1400 y 1767 funcionaron en las posesiones coloniales de Portugal y España.

8 En la Sevilla del Descubrimiento consta la participación de negros danzantes en algunas procesiones importantes, como la del Corpus; en ésta eran conocidos como "diablitos", que representaban el desorden y el pecado que el sacramento de la eucaristía venía a redimir. Según I. Moreno "están documentados al menos 21 grupos de danzantes en Sevilla, desde mediados del siglo XVI a mediados del XVII, con los expresivos nombres de Los negros, Los negros de Guinea, La cachumba de los negros, Los reyes negros o La batalla de Guinea, esta última compuesta de "ocho hombres y cuatro mujeres y un tamboril y una guitarra, los cuatro con panderetes y sonajas y los otros cuatro con atabalillos y las cuatro mujeres con sonajas y banderas". (La antigua Hermandad de los negros de Sevilla. Etnicidad, Poder y Sociedad en 600 años de Historia, Sevilla, 1997, pág. 54). 
nias del culto católico, casi siempre acompañadas de música y canto y de todo un aparato teatral y solemne, muy a gusto con las tradiciones y manifestaciones culturales de indios y negros, fueron utilizadas ampliamente por los religiosos para captar la atención de ambos pueblos. En lo que se refiere al territorio objeto de nuestro estudio, anotemos esta interesante referencia sobre la labor de catequesis realizada entre los esclavos por los jesuitas en el arrabal de Santa Ana, extramuros de la ciudad de Panamá: "Allá acuden los negros bozales - escribe el padre Bernardo Recio en 1748 - con sus tambores y cantinelas; y allá iban los nuestros a adoctrinarles y llevándolos en procesión cantando, concluían con la plática en la iglesia de Santa Ana".

La cofradía como organización religiosa, que como tantas otras cosas se había iniciado en la Península, pasó de inmediato a América donde hasta cierto punto suplantó con notable éxito — según Robert Ricard- a las antiguas fiestas paganas. ${ }^{10}$ En efecto, la Iglesia hizo todo cuanto pudo para conseguir que los negros, al igual que españoles e indios, formaran sus cofradías y hermandades propias en tanto que no solían ser admitidos en las de los blancos. Estas asociaciones religiosas, con fines benéficos y asistenciales, reforzaron con la celebración colectiva de rituales y ceremonias la amistad y la identidad étnica de los africanos, proporcionándoles la ayuda material necesaria para hacer frente a algunos de los apremios más indispensables en el ciclo vital, especialmente en el tránsito hacia el más allá. Más discutible parece, en cambio, que sirvieran para "conservar vivos los cultos afroamericanos", ${ }^{11}$ sino más bien para realizar una lenta, pero eficaz, labor de sincretismo religioso y finalmente de desculturización casi total. Creadas, pues, con propósitos religiosos dentro de un orden social discriminatorio, las cofradías brindaron a los negros "un sentimiento de identidad y de valía que, como los cuerpos de milicia, les ayudó a sobrevivir en un medio netamente racista". ${ }^{2}$ Por último, es interesante tener en cuenta que las cofradías de negros no abandonaron su enclaustramiento étnico hasta el siglo XVIII, cuando comienzan a admitirse como hermanos a algunos blancos. Desde este punto de vista podría decirse que los negros practicaron, a su vez, una forma de segregación que parece impropia de un grupo sometido. ¿Pero realmente esa apertura fue propiciada por ellos mis-

9 Recio, P. Bernardo, S.J.: Compendiosa Relación del Reino de Quito, edición del P. García Goldaraz, S.J., Madrid, 1947, pág. 152.

10 La conquista espiritual de México, México, 1986, pág. 289.

11 Esa es la opinión que sostiene Klein, Herbert S.: La esclavitud africana en América Latina y el Caribe, Madrid, 1986, pág. 149.

12 Ibídem. 
mos, o más bien consentida por una sociedad cada vez más mezclada, heterogénea y tolerante? ¿Había en tiempos pasados muchos blancos, con su prurito de calidad social y su altanería, dispuestos a ingresar en una cofradía de negros?

\section{Cofradías de negros en Panamá ${ }^{13}$}

La presencia de los africanos en Panamá reviste una importancia extraordinaria y no suficientemente reconocida. Como ya observó Luis Navarro, en muy pocos años el Istmo se convierte en el primer territorio americano de población mayoritariamente negra y esto ocurre un siglo antes de que se asienten las grandes concentraciones de esclavos en las Antillas menores, francesas e inglesas. ${ }^{14}$ Con el transcurso del tiempo la supremacía del elemento de color resulta abrumadora, y ya a comienzos del siglo XVII los negros representan algo más del $70 \%$ del total de la población. Un siglo más tarde su presencia sigue siendo abrumadora. En 1778, por ejemplo, había 33.000 personas de color libres y 3.500 esclavas, y esas 33.000 representaban la mitad de la población total. ${ }^{15}$

Las primeras noticias sobre la existencia de cofradías de negros en Panamá que poseemos hasta la fecha datan de comienzos del siglo XVII, aunque es seguro que las primeras debieron organizarse mucho antes. Un informe del guardián del convento de San Francisco, de 1603, habla de la cofradía de Nuestra Señora, que lo era “de todos los negros". Debió ser posterior a estos años la erección de otra cofradía "de morenos", la de San Juan de Buenaventura, con sede canónica en el mismo convento franciscano. En fecha por determinar, los hermanos de la cofradía de negros de Santa Ana, sita extramuros de la ciudad de Panamá la Nueva, en el arrabal del mismo nombre, aseguraban allá por el siglo XVIII que los orígenes de su hermandad se remontaban a tiempos muy antiguos, y aseguraban haber perdido sus reglas fundacionales por el incendio sucedido tras el asalto del corsario Henry Morgan que asoló la ciudad de Panamá la Vieja en 1671, provocando su ruina y posterior traslado a un nuevo emplazamiento, a escasas leguas de distancia. Con la misma escasez de datos nos movemos respecto a los oríge-

13 Las probabilidades de la existencia de otras hermandades de morenos en Panamá durante la época colonial no son escasas. Este estudio constituye sólo un avance de un trabajo de investigación en curso que seguramente arrojará nuevos datos.

14 En el Prólogo de mi obra La Sociedad de Panamá en el siglo XVI, Sevilla, 1984, pág. 21.

15 Klein: La esclavitud..., pág. 142. 
nes de otra cofradía de negros, fundada en Panamá en fecha sin determinar bajo la advocación de Nuestra Señora de la Concepción, con sede en el convento de monjas del mismo nombre. En la iglesia catedral se había establecido ya en el siglo XVII la cofradía de San Sebastián, de la cual nos habla el maestrescuela Juan Requejo y Salcedo en $1640 .{ }^{16}$ Posiblemente se trate de la misma cofradía que en 1775 recibe la aprobación de sus reglas por el Consejo de Indias y a la que luego nos referiremos.

Por último, no podemos pasar por alto el intento de fundar una nueva cofradía "para pardos y morenos libres" que se registra en 1765, pues, aunque desconocemos si obtuvo la correspondiente sanción canónica, conviene tenerlo presente. La propuesta fue planteada ante las más altas instancias por Asensio María Torres y Carrasquilla, natural de Panamá y capitán de una de las compañías de milicias de pardos, quien relataba en su informe que:

"Con motivo de los reiterados incendios que ha sufrido la ciudad y falta de comercio por la supresión de galeones a Portobelo y giro de registros por Buenos Aires y cabo de Hornos la ciudad se halla en la mayor decadencia... siendo esta la causa de que no se pueden dedicar, como antiguamente lo hacían al ejercicio de la caridad con los pobres. Pues aunque en la ciudad está el Hospital de San Juan de Dios para hombres, al cuidado de los religiosos de esta Orden sólo tienen dos salas, la una en que se cura la tropa y la otra en que se reciben los pobres enfermos. Y a extramuros de la ciudad hay una casa hospital para mujeres que se llama Santo Tomás, con muy poca capacidad pues sólo tiene una sala y muy pocas rentas y los dementes andan pululando por calles y plazas 'con la más vergonzosa indecencia', sufriendo las inclemencias del tiempo y durmiendo en los portales y arrojándose al mar, mueren ahogados.

SOLICITA: Que en el arrabal de la ciudad, en el lugar que llaman de la Quebrada, en donde hay muchas quintas de recreo que se dan a censo, se funde un Hospicio para recoger a todos estos desvalidos con separación de dos salas (una para cada sexo), con una iglesia y capellán, con una cofradía con el título de La Caridad, cuya hermandad sea de pardos y morenos libres, que por ser inclinados a ejercitar la caridad cristiana se dedicarán con mayor esmero a contribuir con sus limosnas para la manutención y subsistencia". ${ }^{17}$

En resumen, en 1765 se presentaba ante el Consejo de Indias un proyecto de erección de un hospital para pobres en el extramuros de la ciudad con su propia cofradía, cuya titulación indica el propósito más inmediato que mueve a la hermandad: la atención hospitalaria de los más necesitados. Cofradía de un colectivo: el de pardos y morenos libres, al que se destaca por su inclinación al ejercicio de la caridad cristiana.

16 Requejo y Salcedo, Juan: Relación histórica y geográfica de la provincia de Panamá, por... Año 1640, en Serrano y Sanz, Manuel: Relaciones Histórico-Geográficas, tomo VIII, Madrid, 1908. El original se conserva en la Biblioteca Nacional de Madrid, Manuscritos de América, signatura 676.

17 Archivo General de Indias de Sevilla (en adelante, AGI), Panamá, 275, doc. 10. 
El rastreo de las fuentes suele convertirse en tarea ingrata cuando el investigador busca la respuesta sin encontrarla, aunque también es cierto que la suerte algunas veces acompaña. Eso creo que ha sucedido en este caso, ya que conseguimos encontrar las reglas fundacionales de tres cofradías de negros (la de Santa Ana, La Concepción y San Sebastián) con una valiosísima información que a continuación pasamos a analizar.

\section{COFRADIAS DE NEGROS EN PANAMA}

\begin{tabular}{|c|c|c|c|}
\hline Advocación & Sede canónica & Fecha fundación & Fuente y año \\
\hline $\begin{array}{l}\text { Cofradía de } \\
\text { San Sebastián }\end{array}$ & Catedral & $\begin{array}{l}\text { ¿Antes de } 1640 \text { ? Sus reglas } \\
\text { aprobadas en } 1775\end{array}$ & $\begin{array}{l}\text { Desc. 1640; AGI, } \\
\text { Panamá, } 279 \text { (1775) }\end{array}$ \\
\hline $\begin{array}{l}\text { Cofradía de San Juan } \\
\text { de Buenaventura }\end{array}$ & $\begin{array}{l}\text { Convento de } \\
\text { San Francisco }\end{array}$ & Antes de 1640 & Desc. 1640 \\
\hline $\begin{array}{l}\text { Cofradía de } \\
\text { Nuestra Señora }\end{array}$ & $\begin{array}{l}\text { Convento de } \\
\text { San Francisco }\end{array}$ & Antes de 1603 & $\begin{array}{l}\text { AGI, Panamá, } 103 \\
\text { (1603) }\end{array}$ \\
\hline $\begin{array}{l}\text { Cofradía de Nuestra Señora } \\
\text { de la Concepción }\end{array}$ & $\begin{array}{l}\text { Convento de monjas } \\
\text { de la Concepción }\end{array}$ & $\begin{array}{l}\text { Siglo XVI. Sus reglas } \\
\text { aprobadas en } 1794\end{array}$ & $\begin{array}{l}\text { AGI, Panamá, } 291 \\
\text { (1797) }\end{array}$ \\
\hline Cofradía de Santa Ana & $\begin{array}{l}\text { Ermita/Parroquia de } \\
\text { Santa Ana (arrabal) }\end{array}$ & $\begin{array}{l}\text { Siglo XVI. Sus reglas } \\
\text { aprobadas en } 1775\end{array}$ & $\begin{array}{l}\text { AGI, Panamá, } 279 \\
\text { (1775) }\end{array}$ \\
\hline Cofradía de La Caridad & "La Quebrada" (arrabal) & Proyecto de fundación en 1765 & $\begin{array}{l}\text { AGI, Panamá, } 275 \\
\text { (1765) }\end{array}$ \\
\hline
\end{tabular}

\section{Fundación de las hermandades y sus orígenes étnicos}

En el centro neurálgico del arrabal de Santa Ana que dominaba el recinto amurallado de Panamá la Nueva se encontraba la iglesia parroquial del mismo nombre,$^{18}$ considerada como la segunda catedral de Panamá, que había sido reedificada en 1764 por obra de un piadoso benefactor, el comerciante vasco don Mateo de Izaguirre, ennoblecido tras haber hecho fortuna en América con el título de marqués de Santa Ana y muy dado a las obras de caridad. ${ }^{19}$ Allí, frente al barrio negro de Malambo, tuvo su sede la cofra-

18 "Dicha iglesia de Santa Ana está en el arrabal, que es la mejor pieza de Panamá, y parece ciudad, si no en lo excelso de la fábrica, a lo menos en lo numeroso del pueblo, en el tráfago y comercio, y en el buen orden de su repartición. Tiene plaza muy lucida, calles anchas y muy bien derechas" Recio: Compendiosa Relación..., pág. 152.

19 Según Juan B. Sosa, Santa Ana fue en sus comienzos una pequeña ermita levantada para los feligreses del arrabal de la nueva Panamá en 1677, repitiendo los mismos nombres y esquemas urbanos que en la ciudad abandonada, en donde igualmente existió una ermita en el extrarradio, en las cercanías de los barracones negros de Pierde Vidas y Malambo. Esta ermita fue elevada al rango de parroquia un año más tarde: Panamá la Vieja, Panamá, 1919, págs. 87-88. 
día de la Señora Santa Ana. El arrabal contaba con un numeroso vecindario que, según se estimaba en 1737, "superaba las 20.000 personas capaces de la Sagrada Comunión", en su mayor parte de negros, mulatos y zambos libres, ${ }^{20}$ de manera que no puede extrañar que sea precisamente aquí en donde surja una de las principales cofradías de negros de la ciudad.

No se sabe de cuándo data su fundación. Sus hermanos cofrades se vanagloriaban de que esta hermandad y cofradía de Santa Ana era la más antigua de las existentes en Panamá, remontando su origen "desde los principios del descubrimiento de la dicha ciudad y reino de Tierra Firme, según consta por monumentos (sic) antiguos de 141 años a esta parte". Cuando esto exponían, en un expediente remitido en 1765 al Consejo de Indias para la aprobación de sus nuevas reglas, no tenían documentos que respaldasen tal afirmación, pues al igual que en el caso de la cofradía de la Concepción, a la que luego nos referiremos, aquellos se habían perdido a causa de un incendio: "cuya capilla juntamente con los papeles y constituciones fueron quemados por la invasión y hostilidad de los ingleses". ${ }^{21}$ Se referían seguramente al ataque del corsario inglés Henry Morgan, que - como ya dijimos- asoló la ciudad de Panamá la Vieja en 1671, provocando su ruina y posterior traslado a un nuevo emplazamiento.

Probablemente exageraban en su afán, más que lógico y muy frecuente en todas las cofradías, ya fueran españolas o americanas, de ostentar el número uno entre las de más solera. Sabemos que en la primitiva ciudad de Panamá existía una pequeña ermita bajo la advocación de Santa Ana que había sido edificada por iniciativa del chantre de la catedral, Francisco Díaz, y por el clérigo Juan de Soto, en el camino a Portobelo, muy próxima al puente sobre el río Gallinero. ${ }^{22}$ Allí fue establecida la primitiva hermandad: "Por parte de vos los cofrades de la cofradía fundada bajo la advocación de la gloriosa Santa Ana en su ermita...de la antigua ciudad en la cual estaba dicha cofradía". Pero, ¿de cuándo databa su fundación? Y en el caso de que hubiera sido establecida hacía ya 141 años, o sea en 1624 , tal y como aseguran sus hermanos, ¿por qué no la menciona, junto a otras hermandades de morenos, Juan de Requejo, tan minucioso en su informe

20 Mena García, Carmen: La ciudad de Panamá en el siglo XVIII. Trazado urbano y técnica constructiva, Panamá, 1997, págs. 22 y 23.

21 AGI, Panamá, 279. "Aprobación de las Constituciones nuevamente formadas para la cofradía de Santa Ana, fundada en la iglesia parroquial de este título, extramuros de la ciudad de Panamá". San Ildefonso, 22 de septiembre de 1775.

22 Mena García, Carmen: La ciudad en un cruce de caminos. (Panamá y sus orígenes urbanos), Sevilla, 1992, pág. 184. 
de 1640? Además, como puede observarse en el cuadro que hemos elaborado, para esa fecha ya se habían establecido - con o sin reglas- en Panamá otras muchas hermandades. En consecuencia no creemos que fuese ésta la cofradía panameña más antigua, aunque sí conviene dar crédito a la memoria colectiva de sus hermanos y confiar en que ya existió una cofradía de Santa Ana en Panamá la Vieja.

Por ahora no es posible saber si los africanos se agruparon en cofradías según sus lugares de procedencia. En el caso peruano parece comprobada la estrecha relación existente entre las "naciones" esclavas y los diferentes cabildos/cofradías de negros ${ }^{23}$ pero los datos disponibles para el territorio panameño no permiten por ahora llegar a ninguna conclusión. Sabemos, eso sí, que la iniciativa de fundación de la cofradía de la Señora Santa Ana había partido de tres familias, pertenecientes a diferentes etnias originarias de Guinea Bissau, tal y como se desprende de sus nombres: "la de Branes (Bran), la de Viojoes (Bioho) y la de Bañones (Bañol)". ${ }^{24}$ La de Santa Ana respondía a un modelo estrictamente étnico y bien delimitado en sus orígenes: era una cofradía exclusivamente de negros (ni siquiera se alude a las mezclas, como mulatos, pardos u otros), según se hizo constar en el capítulo primero de sus reglas:

"Habiendo Dios por gracia especial alumbrado el entendimiento de los primitivos negros para que viniesen en conocimiento de la Santa Fe católica en la ciudad de Panamá, y habiendo determinado estos elegirse por patrono algún santo de la corte celestial les tocó la santa madre Ana para que como abuela de Nuestro Señor Jesucristo implorase el auxilio de su Divina Majestad a favor de ellos que hasta entonces habían estado en las tinieblas de la ignorancia...”

La cofradía de San Sebastián estaba domiciliada, como ya adelantamos, en la iglesia catedral. Y aunque es seguro que en 1640 existía en Panamá Viejo una hermandad con el mismo nombre y en la misma iglesia, lo cierto es que - de tratarse de la misma hermandad, lo cual es más que probable - no dispuso de estatutos definitivos hasta $1775 .{ }^{25} \mathrm{La}$ iniciativa de su erección partió de un heterogéneo grupo de color que aglutinaba a

23 Celestino y Meyers: Las cofradías..., pág. 10.

24 Bran: procede de los Bran, Gola y Burama, originarios de Guinea-Bissau; Bioho: procede del grupo africano de los Bissago, originarios de Guinea-Bissau; Bañol, Bañul: procede de los Bauyun, originarios de Guinea-Bissau. Bowser, Frederick P.: El esclavo africano en el Perú colonial (15241650), México, 1977, pág. 418.

25 AGI, Panamá, 279. "Aprobación de las Constituciones nuevamente formadas para la Cofradía de San Sebastián fundada en la iglesia Catedral de Panamá”. San Ildefonso, 22 de septiembre de 1775. 
negros, tanto libres como sometidos a esclavitud, y a zambos. Curiosamente el resultado de la mezcla racial negro/indio, conocida frecuentemente como zambos, recibía en Panamá una denominación peculiar: la de morenos criollos, o simplemente criollos. Así se expresa en algunos pasajes del expediente fundacional y muy particularmente en el capítulo preliminar de sus reglas:

"Habiendo Dios, nuestro señor, por su infinita misericordia, alumbrado el entendimiento de los hijos de los negros e indios, llamados comúnmente morenos criollos, y el de los negros libres y_cautivos para que conociesen el incomparable tesoro de nuestra santa fe católica...que fueron nuestros fundadores".

Todos sus hermanos sabían por tradición oral que la cofradía a la que pertenecían era muy antigua, pero no disponían de documento alguno que lo acreditase. Así lo exponía ante el obispo su mayordomo, Juan José Carrillo:

"...que nuestros antepasados, movidos de la piedad, y para mayor culto de dicho glorioso mártir (San Sebastián) fundaron dicha cofradía, según se sabe por tradición, no habiendo quedado ningún documento de ello, y mediante que dicho exponente y todos los demás cofrades para el buen gobierno de ella y para mayor culto y veneración de dicho glorioso santo, desean tener estatutos, o sea constituciones..."

Los orígenes de la cofradía de negros de Nuestra Señora de la Concepción, situada en el único convento de monjas que había en Panamá, tampoco pueden precisarse. Los hermanos cofrades y la abadesa del monasterio, madre doña Petronila Sánchez de la Peña, aseguraban en la segunda mitad del siglo XVIII que databa de muy antiguo, mucho antes desde luego del traslado de la ciudad: "Esta cofradía, señor, es establecida de tiempo inmemorial de más de dos siglos a esta parte...”, pero decían no recordar con exactitud la fecha de la erección, pues sus papeles, entre ellos la Real Licencia y la Bula Pontificia, desaparecieron en el gran incendio que asoló la ciudad de Panamá el 2 de febrero de $1737 .{ }^{26}$ Lo que sí está suficientemente documentado es que la hermandad — con o sin papeles, legalmente establecida o no- celebraba sus cultos en el siglo XVIII con gran dedicación y provecho y con gran holgura económica, al menos así lo aseguraban sus hermanos y ratificaba el provisor del obispado en sede vacante, don Nicolás de Arechua y Sarmiento, quien en 1781 escribe a la Corona

26 AGI, Panamá, 291. Expediente sobre la aprobación de las reglas de la Cofradía de la Concepción de Panamá. Panamá, 8 de octubre de 1793. 
que (la cofradía de La Concepción) es "la más abundante de hermanos y de más fondo por el mayor número de limosnas y por los muchos que en ella se alistan estimulados de la puntualidad con que son servidas sus funciones y la arreglada inversión que se hace de sus fondos".

Hasta la fecha se desconoce el primitivo lugar de su ubicación, pero lo más seguro es que estuviera asentada en el mismo convento de monjas de la Concepción que ya existiera en Panamá la Vieja, en la calle de la Empedrada, desde fines del siglo XVI. Sus primeros hermanos fueron, al igual que en la cofradía de San Sebastián, negros y zambos, y más concretamente un grupo de negros procedentes de Etiopía: “...determinaron los antepasados etíopes y criollos morenos fundar una cofradía, como lo hicieron a costa de sus propias limosnas, poniéndola por norte cofradía y hermandad, con el título de la Purísima Concepción, que es venerada en el monasterio de las Concebidas de esta ciudad".

\section{Las cofradías y sus reglas constituyentes}

Los libros de Regla constituyen —según Teresa Laguna— "la principal fuente jurídico-normativa del gobierno, administración e historia de las hermandades". ${ }^{27}$ Todas las cofradías redactaban sus reglas y tenían sus propios estatutos en los que organizaban la vida interna de la comunidad religiosa. Es de suponer que casi todas se ajustaron a una especie de plantilla general a la que se incorporaron algunos rasgos peculiares e identificativos de cada cofradía, al igual que sucede hoy día con la normativa que rige a las distintas asociaciones. Las normas para ser sancionadas variaron al compás de los tiempos, y en este sentido conviene recordar que la obligación ineludible de aprobación eclesiástica de las Reglas de las hermandades y cofradías - a uno y otro lado del Atlántico— no se generaliza hasta después del Concilio de Trento, dentro del "nuevo espíritu de fiscalización que el concilio trae" y "como producto de una necesidad de control sobre los fenómenos de asociacionismo". ${ }^{28}$ No obstante, como acertadamente observa I. Moreno en el caso de Sevilla, "un buen número de ellas, sobre

27 "Regla de la Cofradía de la Santísima Veracruz", Velázquez y Sevilla, Sevilla, 1999, tomo II, pág. 124.

28 Lara Ródenas, J.M.: "Organización interna y estructuras de poder de las Hermandades de Huelva durante el antiguo régimen”, Gremios; Hermandades y Cofradías, San Fernando, 1992, tomo I, págs 21-242. Citado por Moreno: La antigua hermandad..., pág. 59. 
todo de fuera de la ciudad, hicieron caso omiso de esa obligación, como se demuestra en los informes de finales del siglo XVIII". ${ }^{29}$

Muchas cofradías americanas, que presentaron ante el Consejo de Indias sus constituciones fundacionales a lo largo del siglo XVIII, no fueron aprobadas por no cumplir con los requisitos legales que, tal y como se hacía constar al ser devueltas, consistían en los siguientes:

"Para fundar Cofradías, Juntas, Colegios o Cabildos de españoles, indios, negros, mulatos u otras personas de cualquier estado o calidad, aunque sea para cosas y fines píos y espirituales, preceda licencia nuestra y autoridad del prelado eclesiástico, y habiendo hecho sus ordenanzas y estatutos las presenten en nuestro Real Consejo de las Indias para que en él se vean y provea lo que convenga, y entre tanto no puedan usar ni usen de ellas; y si se confirmaren o aprobaren, no se puedan juntar ni hacer cabildo ni ayuntamiento si no es estando presente alguno de nuestros ministros reales que por el virrey, presidente o gobernador fuere nombrado, y el prelado de la casa donde se juntaren". ${ }^{30}$ (Ley 29, tít. 4, lib. 1 de la Recopilación de las Leyes de Indias de 1680).

En el siglo XVIII, la política del regalismo borbónico se muestra abiertamente contraria a la proliferación incontrolada de asociaciones religiosas en América, muchas de las cuales consideraba no sólo carentes de utilidad pública e innecesarias, sino incluso perjudiciales para el bien del Estado. ${ }^{31}$ Así se puso de relieve en la sentencia del fiscal del Consejo, dada el 10 de septiembre de 1779, en relación a la solicitud presentada por los hermanos de Nuestra Señora del Carmen para la erección de una cofradía bajo la citada advocación en la iglesia parroquial de Portobelo, encontrándose con esta airada respuesta:

"Que reconociendo las leyes de Castilla e Indias la poca utilidad que de estas congregaciones se sigue al Estado y aún al culto divino, tiene prohibido expresamente el que se formen alguna sin que precedan las licencias de S.M. y de los respectivos ordinarios, pues de este modo se consigue que sólo se erijan aquellas que sean útiles para mayor aumento del culto divino y no perjudiciales al Estado y causa pública...”32

A la vista de las peculiaridades, casi anecdóticas, que separan las constituciones de las cofradías de negros que analizamos y de los diferentes preceptos que las regularon, podemos adelantar que en todas ellas se

29 Ibídem, págs. 59 y 60.

30 Ley 29, tít. 4, lib. 1 de la Recopilación de las Leyes de Indias de 1680.

31 Martínez de Codes, Rosa M. a: "Cofradías y capellanías en el pensamiento ilustrado de la administración borbónica (1760-1808)”, Cofradías, Capellanías y Obras Pías en la América Colonial, México, 1998, págs. 17-35.

32 AGI, Panamá, 284. 
observan grandes semejanzas que con seguridad provienen de la identidad étnica de sus hermanos, de sus raíces culturales y de su desvalida situación socio-económica. A grandes rasgos, lo primero que destaca en las constituciones de estas hermandades es que, a diferencia de las reglas pertenecientes a cofradías de españoles, que suelen iniciarse simplemente con una invocación al Espíritu Santo, en las de negros todas van precedidas de una manifestación pública de fe y de conversión al catolicismo por parte de los fundadores de la hermandad, negros y morenos de cualquier condición jurídica:

"Con motivo de haber Dios, nuestro Señor, dado luces a los etíopes y criollos morenos libres para que conociesen el tesoro de nuestra santa fe católica, determinaron tener alguna particular devoción a quien tributar sus más reverentes cultos..." (Cofradía de la Concepción, cap. 1).

"Habiendo Dios, nuestro Señor, por gracia especial alumbrado el entendimiento de los primitivos negros para que viniesen en conocimiento de la santa fe católica en la ciudad de Panamá, más de cien años ha, y habiendo determinado éstos elegirse por patrono algún santo de la corte celestial, les tocó la santa madre Ana". (Cofradía de Santa Ana, cap. 1)

"Habiendo Dios, nuestro Señor, por su infinita misericordia, alumbrado el entendimiento de los hijos de los negros e indios, llamados comúnmente morenos criollos, para que conociesen el incomprensible tesoro de nuestra santa fe católica, determinaron estos elegirse un especial patrono y obsequiarle con un culto fervoroso y manifestar de este modo el celo y afición que tenían a las cosas divinas y eligieron al glorioso mártir San Sebastián”. (Cofradía de San Sebastián, cap.1).

La necesidad de demostrar algo por parte de un colectivo —en este caso la renuncia a sus ritos africanos de origen y su sustitución, más o menos sincera, por una religión que le es ajena y ha sido impuesta por la fuerzaimplica automáticamente un reconocimiento de ser sospechoso ante otros. Por eso los negros necesitaban expresar su sometimiento a la religión de sus amos y al mismo tiempo a sus estrategias de dominio, con fórmulas como las que acabamos de ver. Los negros que fundan estas devociones seguramente ya han dejado de ser un peligro, un potencial foco de inestabilidad en el cuerpo social, pero tienen que manifestarlo una y otra vez, pues sobre ellos planea siempre el estigma de la esclavitud y del paganismo.

Una segunda nota común a las tres constituciones radica en la circunstancia, tal vez nada casual, de que todas fueron redactadas en el siglo XVIII, lo cual no excluye que su origen no fuera mucho más antiguo. En efecto, las reglas de la Pontificia Hermandad de Santa Ana se remontan al 
último tercio del siglo XVIII, ya que consta que obtuvieron del Consejo de Indias la preceptiva "Real Licencia" el 12 de agosto de 1775, recibiendo además el respaldo pontificio correspondiente mediante un Breve de S.S. de 15 de marzo de 1774. Son las únicas que hasta la fecha se conocen, aunque no debieron ser las primeras, según se desprende del título y contenido del expediente enviado al Consejo unos años antes: "Aprobación de las constituciones nuevamente formadas para la cofradía de Santa Ana fundada en la iglesia parroquial de este título, extramuros de la ciudad de Panamá". ${ }^{33}$ En el mismo se expresan también las razones que movieron a la Hermandad a redactar nuevas reglas y a las que indirectamente nos referimos más atrás: las antiguas se perdieron en la gran conflagración que asoló la ciudad de Panamá tras el asalto inglés de 1671.

Las reglas de la Pontificia Hermandad de San Sebastián datan también del último tercio del siglo XVIII, pues consta que fueron aprobadas el 13 de septiembre de 1770 - a los dos meses de ser redactadas- por el obispo de Panamá, electo de la diócesis de Huamanga, don Miguel Moreno y Ollo, quien otorgó a todos sus hermanos 40 días de indulgencia plenaria. El 5 de marzo de 1774 la Hermandad obtuvo un Breve Pontificio que sancionaba su erección y el 12 de agosto de 1775 el correspondiente "pase" del Consejo de Indias y la Real Licencia del monarca. ${ }^{34}$

La cofradía de la Purísima Concepción tuvo que someterse, en cambio, a un largo y durísimo proceso hasta ver ratificados sus estatutos. En 1753 sus hermanos iniciaron los tramites previstos presentando sus reglas ante el gobernador de Panamá, don Manuel de Montiano, quien les concedió la licencia correspondiente en ese mismo año. Hasta 1766, por razones que no se aclaran en el expediente, el proceso estuvo detenido, pues consta que hasta ese año no fue ratificada por el obispo don Miguel Moreno y Ollo. Sin embargo, circunstancias desafortunadas alargaron desesperadamente el proceso en su tercer y último escalón. Circunstancias tales como la ineficacia de los apoderados nombrados por la cofradía ante el Consejo que hasta en número de tres fueron enviados a Madrid, uno tras otro, para sacar el

33 AGI, Panamá, 279. En realidad fueron redactadas el 10 de agosto de 1666 y confirmadas cuatro días más tarde, por el obispo de Panamá, quien concedió en el mismo acto 40 días de indulgencia plenaria a todos los cofrades. En el expediente consta que el notario mayor José Gromin y Toledo certificó una copia de las mismas el 16 de agosto de 1742. Un nuevo traslado y certificación fue realizado el 29 de noviembre de 1765 por el escribano público, Antonio Franco. Finalmente, el asiento de los hermanos de la cofradía lleva por fecha 4 de diciembre de 1765.

34 Curiosamente ambas cofradías, la de Santa Ana y la de San Sebastián, recibieron en una misma fecha los correspondientes permisos tanto episcopal, como apostólico y real. 
expediente del atolladero en que estaba metido, ${ }^{35}$ la larga enfermedad del obispo de Panamá, que le impidió contestar a las demandas del Consejo recabando información sobre la cofradía; la desidia de los gobernadores panameños; la lentitud burocrática, etc., llevaron a la cofradía al borde de su desaparición. De hecho, durante algunos años estuvo suspendida de facto, pues una real cédula dirigida al gobernador de Panamá el 19 de enero de 1782 lo conminaba a prohibir la celebración de los actos religiosos de la Hermandad de la Concepción "hasta que no se obtenga para ello mi real permiso". Finalmente, cuando parecía que ya todo estaba perdido, precisamente en un momento en que soplaban vientos contrarios a estas asociaciones religiosas, el expediente salió adelante y las reglas fueron aprobadas por el Consejo de Indias en su reunión de 29 de julio de 1794.

Las constituciones de la antigua cofradía de Santa Ana se componen de 11 artículos y reflejan en principio un modelo de asociación religiosa cerrada en torno a una misma etnia: la raza negra — en estado de libertad o esclavitud-, tal y como se hizo constar en el primero de los artículos redactado a modo de introducción o preámbulo. En el mismo se recoge también a sus fundadores, así como los fines espirituales perseguidos por la hermandad. Sin embargo, conviene precisar que tal autoproclamación como cofradía de una sola etnia, formulada en el primero de sus capítulos, debió ser respetada en sus orígenes fundacionales, más no ahora, cuando había transcurrido más de un siglo y la sociedad de castas había alcanzado su máximo desarrollo. La hermandad no pudo seguramente resistirse al empuje de las mezclas raciales que caracteriza al siglo XVIII, y aunque manteniendo su identidad étnica como nota predominante abrió las puertas también a otros grupos raciales, ya fuesen blancos, mulatos u otras mezclas, reconocidas genéricamente como "gentes de color". Así se desprende del catálogo de los hermanos que integraban la cofradía — convertida ya en asociación multiétnica - cuando fueron redactadas sus nuevas reglas y que fue incorporado al final del expediente remitido al Consejo de Indias para su aprobación, como más adelante veremos.

Las reglas de la Hermandad de San Sebastián se componen de 18 capítulos y en ellas se reproduce todo lo anteriormente expuesto. La asociación engloba exclusivamente en sus orígenes a los negros y a un sector de las castas: "los dichos hijos de los negros e indios, llamados comúnmente morenos criollos y los negros libres y cautivos, nuestros antepasados...".

35 Existía un gran descontento en especial con el primero de ellos, el presbítero y aspirante al ducado de Gandía, don Francisco de Borja, al que se acusaba de inepto. 
Pero, a mediados del siglo XVIII, cuando fueron redactadas sus reglas, no existía ningún obstáculo para la admisión de cofrades blancos en el seno de la Hermandad e incluso se les reservó cargos de responsabilidad, como más adelante veremos.

Las constituciones de la cofradía de Nuestra Señora de la Concepción son - a diferencia de las anteriores - más completas y detalladas y constan de 44 artículos, precedidos de una introducción, en la que de modo solemne se declaran los propósitos espirituales que guían a la Hermandad. Representan asimismo "un modelo estrictamente étnico y cerrado" en sus orígenes, pues sólo a los negros se les reconoce como posibles hermanos: “...determinaron los antepasados etíopes y criollos libres fundar una cofradía...”. Con el paso del tiempo, sin embargo, inicia igualmente un proceso de blanqueamiento, al permitirse el ingreso de hermanos de raza blanca, proceso que no es, en modo alguno, ajeno al notable empuje ascensional de la sociedad de castas en el Panamá de mediados del siglo XVIII. Desde hace unos años la población soporta a duras penas la crisis del tráfico interoceánico, que afecta muy especialmente a un territorio que basa su prosperidad en torno al sector del comercio y servicios. Para la élite panameña cada vez resulta más difícil adquirir y tener a su servicio una mercancía tan costosa. Coincidiendo con esta crisis, la hermandad de la Concepción experimenta, sin embargo, un notable afianzamiento que encuentra reflejo en el acrecentamiento, en cantidad y calidad, de su patrimonio y en su total integración en la vida religiosa de la ciudad que ya a comienzos del siglo XVIII parece bien manifiesta. ${ }^{36}$ Esta aparente contradicción puede interpretarse de la siguiente forma: en la medida en que desciende el número de esclavos y aumenta el de los libertos de color en su variada gama de mezclas, respecto al conjunto de la población panameña, dejan de ser un peligro, un potencial foco de inestabilidad en esta sociedad rígidamente estratificada y jerarquizante del Antiguo Régimen, al tiempo que se hace más fácil su integración en el cuerpo social. "Garantes del equilibrio social — escribe Omar Jaén— los libertos de color han permitido, en parte, la relativa tranquilidad interior que demuestra la sociedad panameña integrada, sometida a la autoridad durante la mayor parte de la época colonial". ${ }^{37}$ Casi todos los morenos, en la segunda mitad del siglo XVIII, tanto libres como sujetos a esclavitud, estaban ya fuerte-

36 Buena prueba de ello lo encontramos en el patrimonio exhibido por la Hermandad, a raíz del incendio de 1737.

37 Jaén, Omar: La población del Istmo de Panamá. Estudio de Geohistoria, 3. ${ }^{\text {a }}$ edición, Madrid, 1998, pág. 389. 
mente transculturados, al ser muchos de ellos hijos o hijas de otros morenos que habían vivido toda su vida en Panamá o en otros lugares de América. ${ }^{38}$

Continuando con el análisis de las constituciones, en lo que respecta a la cofradía de Santa Ana, el capítulo 2 regula las elecciones de los cargos directivos, disponiendo que anualmente se celebren éstas el 10 de agosto, día de San Lorenzo. Por la mañana, tras la celebración de una misa del Espíritu Santo, "para que alumbre su entendimiento", la directiva saliente procederá a la elección del hermano mayor, mayordomos y demás oficiales, estableciéndose como único requisito que los elegidos "han de ser de buena vida y costumbres". Las elecciones son abiertas y permiten la participación de todos los hermanos cofrades, quienes serán avisados previamente mediante el sonido de una campanilla, que recorrerá las calles de la ciudad anunciando la junta general, a la que están obligados a concurrir, a las tres de la tarde de ese mismo día, multándose con una libra de cera a todo aquel que siendo avisado no acudiere. La dificultad para emitir el voto por escrito se deriva del alto grado de analfabetismo de muchos de los electores : "mediante que la mayor parte de los cofrades no saben leer ni escribir por lo cual no se pueden hacer las elecciones por cédulas". Por eso, el artículo 3 contempla la posibilidad de que los hermanos emitan su voto de viva voz. El presidente de la junta electoral, con asistencia de un escribano nombrado por el obispo, registrará por escrito los votos. El resultado final de las elecciones no será válido mientras no sea confirmado por el obispo de la diócesis y, en ausencia de éste, por el cabildo eclesiástico.

Tanto en este artículo como en los siguientes se contienen interesantes referencias a los mayordomos de la cofradía que merecen un breve comentario. En primer lugar se contempla la posibilidad de que puedan acceder al cargo tanto hombres como mujeres ("mayordomas"). Pero mientras que en el caso de éstas últimas no se precisa su número, ni el modo en que son elegidas, en el de los mayordomos se estipula que deben ser tres: "uno para cada casta", y aunque no se especifica a qué grupo racial corresponde cada casta, es de suponer que se piensa en blancos, negros y mezclas en toda su amplia gama. Esta distinción entre mayordomos para una u otra etnia, de marcado carácter segregacionista, demuestra que los prejuicios de la sociedad de castas traspasaban las barreras más elevadas, incluso las espirituales.

En el capítulo 4 se establecen las obligaciones de los mayordomos/as consistentes en la visita de la iglesia parroquial, alternándose cada uno de

38 Ibídem, págs. 384 y ss., trata la disminución de la entrada de negros bozales en el territorio panameño y la progresiva criollización de éstos — tanto esclavos como libres-. 
ellos por semana, colaborando con el teniente de cura en todo lo necesario "para el culto de Dios y para el aseo de la iglesia, de los altares y de los cementerios". Sólo en esto consistirá su labor "y no han de estar obligados a otra cosa ni se les pondrá mandar nada más". Anotemos que no se establece ninguna diferenciación respecto a las atribuciones de los mayordomos, según fueran hombres o mujeres.

Más adelante se reglamenta el orden que ha de guardarse cuando se celebre la junta general de la Hermandad, que debe estar presidida por el teniente de cura de la iglesia de Santa Ana. En ella debían revisarse sus cuentas, el comportamiento de los mayordomos salientes, la elección de nuevos cargos y otras cuestiones de orden interno. Nadie podía hablar sin ser preguntado por el presidente de la mesa, pues "de este modo se evitará la confusión", estableciéndose severas multas para quienes contravinieren lo así dispuesto (cap. 11).

Anualmente, la cofradía de San Sebastián celebraba un cabildo general para renovar sus cargos de gobierno: un tesorero, un vice-tesorero, cuatro celadores, dos mayordomos, dos diputados y un hermano mayor. Este último cargo debía ser ocupado "para mayor decoro de la cofradía" por un sacerdote, no siendo requisito indispensable su adscripción a la Hermandad. Respecto a los mayordomos interesa resaltar que se acordó la obligada elección de un español para este puesto, a fin de que "cuide de las caridades que diere la cofradía y los cofrades tendrán cuidado de que el que fuere elegido sea de la mayor distinción" (cap. 4). El prurito de inferioridad de los de color aflora en este texto, que aparentemente se contradice más adelante cuando se especifica lo siguiente: "No podrá ser elegido por mayordomo de esta cofradía ningún español ni ninguno otro de los llamados comúnmente de color y si bien deberá ser elegido indispensablemente un hijo de negro e indio, llamado comúnmente moreno criollo, o un negro habiendo sido éstos los primeros fundadores de esta cofradía" (cap. 17). Es posible que el verdadero significado de ambas cláusulas haya quedado oscurecido por una inadecuada redacción del texto. Y puesto que se habla de dos mayordomos, seguramente se reservó un cargo para un español y otro para un zambo o un negro en atención a que fueron miembros de esta etnia los primitivos fundadores de la cofradía.

La junta de gobierno de la Hermandad de la Concepción se renovaba también cada año. El 31 de diciembre, a las 4 de la tarde, todos los hermanos que habían sido convocados a son de campanillas por la calles de la ciudad, debían acudir a la sede de la Hermandad. El mayordomo bolsero presentaba 
las cuentas del ejercicio anterior y se procedía a elegir a los nuevos cargos directivos, que eran los siguientes: un mayordomo bolsero, tres mayordomos, dos mayordomas, cuatro procuradores y cuatro diputados. Además, como cargos de honor integraban la junta: un hermano mayor, que debía ser sacerdote, "atendiendo al mayor lustre de la cofradía" y un prioste, "para que corra con los convites que puedan ofrecérsele a la Hermandad, procurando sea persona de todo lustre para el mayor respeto, aunque no sea hermano". Las elecciones se celebraban por voto secreto y se requería mayoría de dos tercios para la designación del hermano mayor, prioste y mayordomo bolsero, siendo suficiente con la mayoría simple para el resto de los cargos. El capítulo 33 establecía el siguiente requisito para ocupar el cargo de mayordomo bolsero: "Que ningún español ni persona de color ninguno pueda ser mayordomo bolsero de la cofradía, sino precisamente y por obligación ha de ser el que fuere de color moreno, respecto a que los primarios fundadores fueron de la misma calidad y que hasta el presente se ha guardado el mismo orden, lo cual no deberá observarse para los demás cargos de la cofradía".

En algún momento, aún no establecido, de la historia de la cofradía, las mujeres lograron hacerse con ciertos cargos de relativa importancia en la Hermandad, como los de mayordomas, cargos que lo fueron de designación y no de elección. Lo mismo hemos visto que sucedió en la de Santa Ana. Moreno, quien ha puesto al descubierto importantes datos sobre la presencia de mujeres negras en la cofradía sevillana de Nuestra Señora de los Angeles (o de "los Negritos"), ${ }^{39}$ considera que las primeras mayordomas que ocupan este cargo a partir de 1679 en la citada Hermandad desempeñaban las funciones correspondientes a las que más tarde serán conocidas como camareras: cuidado, limpieza y vestido de las imágenes y de todo lo referente al culto de la capilla. Y que, por consiguiente, habría que desechar cualquier idea relativa a la igualdad de oportunidades de ambos sexos en el seno de la cofradía, al menos por ahora. Ningún dato proporcionan las reglas de la Hermandad de la Concepción respecto a las funciones desempeñadas por ambas mayordomas. Sin embargo en el proyecto de cofradía presentado en 1772 con el título de La Caridad, teniendo por sede también la iglesia parroquial de Santa Ana, en el capítulo $4 .^{\circ}$ de sus reglas se dice lo siguiente: "Item en el gremio de las mujeres haya también dos procuradoras que cuiden el aseo y limpieza de los manteles para el altar,

39 Moreno: La antigua hermandad de los negros... Véanse los epígrafes: "La presencia de las mujeres negras", págs. 132 y ss. y "El protagonismo femenino: la Congregación del Rosario...", págs. 174 y ss. 
adorno para la imagen, estandarte y demás de confraternidad". ${ }^{40}$ De lo cual se infiere que al menos aquí el cargo de mayordoma tenía atribuciones muy similares a las camareras de las cofradías actuales. Lo cual no parece quedar tan claro en el caso de la Hermandad de Santa Ana, en donde, como ya vimos, la labor exigida a los mayordomos/as parece más amplia y desde luego no distingue entre ambos sexos. ${ }^{41}$

Las cofradías se sostenían con donaciones piadosas de los vecinos (censos y capellanías) y algunas sólo con las limosnas de sus hermanos. La cofradía de San Sebastián establecía una cuota de entrada de 8 reales (cap. 9) y otra semanal (todos los domingos del año) de medio real, pero además obligaba a todos los cofrades a sufragar los numerosos actos de culto, los benéficos-asistenciales y las festividades de la hermandad. La cofradía de La Concepción exigía una cuota más elevada de 12 reales (cap.12), aunque a cambio el nuevo afiliado recibía de manos del sacerdote-hermano mayor un escapulario bendecido, precisándose que si alguna hermana quería vestir el hábito de la virgen de la Concepción, abonaría, además de la correspondiente cuota de entrada, un peso. Del mismo modo, los hermanos quedaban obligados a contribuir con donaciones piadosas a los gastos de la cofradía, si bien parte de los fondos iban a parar a manos de la madre abadesa del convento en donde tenía su sede, sobre todo con motivo de las celebraciones del culto religioso.

Muy modestas debieron ser las rentas de la cofradía de Santa Ana que se sostenía básicamente de las limosnas que se recogían en las calles y de las que aportaban sus hermanos, llamadas éstas "de entrada y averiguación". La precariedad económica de la hermandad, justificable dada la pobreza de sus miembros, hacía más aconsejable aún reforzar los mecanismos de seguridad para controlar los ingresos y administrar con sensatez sus escasos recursos. Por ser "muy cortas las limosnas que se recogen al cabo del año y las que contribuyen los cofrades", se establecen medidas básicas de orden interno, tales como guardar los fondos en un arca de tres llaves, cada una de ellas bajo la custodia de una persona diferente (el teniente de cura de la iglesia, el hermano mayor y el mayordomo más antiguo), "de manera que no se podrá abrir dicha arca sin que estén presentes los tres"; asentar por castas, y cada una de ellas por orden alfabético la relación de los hermanos en el libro de asiento de la cofradía, acabando con el desor-

40 AGI, Panamá, 283.

41 Curiosamente en el asiento de hermanos de la cofradía de Santa Ana se anota a don Mateo de Izaguirre con el apelativo de “camarero”. 
den que hasta entonces había prevalecido, para llevar cuenta ajustada de los que habían pagado limosna y quienes restaban por hacerlo. El hermano mayor estaba obligado, además, a anotar los nombres de los nuevos afiliados, así como las bajas producidas, para que siempre hubiese constancia cierta del número de sus miembros (caps. 2 y 5 ).

En las constituciones de la cofradía de los negros de la Concepción se contempla también la existencia de libros de registro de la hermandad a fin de asegurar su orden interno (cap. 5). El hermano mayor custodia cuatro libros: uno para asentar el cargo de todas las limosnas recaudadas por el mayordomo y otro para asentar los gastos; un tercero con la nómina de los hermanos; y un cuarto con una copia de las reglas de la Hermandad, así como de las elecciones y juntas de gobierno celebradas.

Los gastos y atenciones de beneficencia con los hermanos merecen una particular atención en las reglas de todas las cofradías de los negros, habida cuenta que la mayoría de sus afiliados era gente necesitada y perteneciente a los estratos marginados de la sociedad. En la cofradía de Santa Ana sus labores benéfico-asistenciales, reguladas en los artículos 6 y 7, se destinaban a la prestación de los últimos auxilios en el trance de la muerte a los que fallecían en el seno de la hermandad, tarea ésta comúnmente presente en la mayoría de las hermandades. Cuando alguno de sus miembros enfermaba, el mayordomo de su casta debía dar aviso a la hermandad para que fuese socorrido "conforme a los fondos de la cofradía". La visita al enfermo, obligación contemplada por la caridad cristiana, de la que debía hacer gala la cofradía, se prescribía como tarea inexcusable, disponiéndose que el mayordomo señalase a varios cofrades para que, por turno, visitasen al moribundo hasta que se produjera el óbito.

Todos los hermanos, ya fueran libres o esclavos, tenían derecho a una muerte y a un entierro dignos. Llegada la hora, el único requisito que se exigía, además de la vinculación con la Hermandad, era estar al día en los pagos correspondientes. Por eso, las reglas obligaban al mayordomo de cada casta a comprobar previamente si el fallecido había cumplido como tal cofrade y, en caso afirmativo, la Hermandad colaboraba con los gastos del funeral, aportando de sus fondos siete pesos, de a nueve reales. Presidía el cortejo fúnebre el estandarte de la cofradía y seis hachas, seguramente de cera, o bien de esparto y alquitrán. Y como siempre hubo clases, incluso a la hora de la muerte, a los miembros de la junta de gobierno - mayordomos u otros - se les reservaba una ceremonia funeraria en la que se cuidaban los detalles con mayor atención que en el caso de los restantes herma- 
nos y que consistía en: "el entierro en la iglesia de Santa Ana, con el paño, cuatro velas y cuatro hachas, misa cantada y oficio, juntándose todos los cofrades para asistir a este funeral". Para sufragar estos funerales distinguidos, se obligaba a los hermanos a entregar sus limosnas - sin especificar la cuantía de la ayuda - que debían ser escrupulosamente anotadas en el correspondiente libro de registros ("registro de la colectoría"). Y para evitar cualquier descuido o malversación de los fondos se estipulaban las siguientes medidas cautelares: en el registro de la colectoría "se escribirá la cantidad recogida y firmará en él el sacerdote que celebrare dichas misas, no pudiendo disponer de dicha limosna que se recogiere ninguno de los mayordomos, y las misas no se podrán celebrar en otra ninguna iglesia, salvo en la de Santa Ana, so pena de reintegrar la cantidad a que asciendan dichas limosnas" Lo sobrante se depositaría en manos del teniente de cura de la parroquia para misas por el sufragio del difunto fallecido (cap. 8).

Igualmente, en el caso de la cofradía de la Concepción, el rito de paso desde la enfermedad hasta la muerte, tan costoso para las clases desposeídas tanto entonces como ahora, mereció una atención especial en sus reglas. También aquí encontramos reguladas fórmulas de fraternidad entre los miembros cofrades, expresadas tanto en lo material (entierro y funeral) como en lo espiritual, que contempla desde la celebración del entierro y misas de réquiem - todo a costa de la cofradía - hasta muestras de consideración para aquellos que fallecieren fuera de la ciudad. Respecto a éstos, el capítulo 20 disponía que "se le cantará una misa con su responso y se dirán tres rezadas, todo a beneficio del hermano o hermana difunta". Se contemplaba asimismo la posibilidad de que el cofrade falleciera en el hospital de San Juan de Dios y fuera allí enterrado (cap. 19) y en ese caso la Hermandad contribuiría con todos los gastos, entregando al citado convento-hospital lo siguiente: "toda la cera que necesitare para el entierro... y diez pesos por la limosna de sepultura que se dará en dicha iglesia y exequias que cantará la comunidad de su convento".

La ayuda al hermano difunto se realizaba ya desde el mismo instante del óbito. Una vez avisado el mayordomo bolsero del fallecimiento de algún hermano debía enviarle lo siguiente: "seis velas de a media libra, seis candeleros, la cuna, cuatro paños negros, una colcha de seda, una almohada, seis hachas, seis hacheros y "para la hora del entierro el estandarte con cuatro velas para que vayan alumbrando a Nuestra Señora los hermanos asistentes". Tras las correspondientes misas de réquiem, con cargo a los fondos de la hermandad, los cofrades recibían cristiana sepultura en la pri- 
mera nave del convento de la Concepción, sede de la cofradía, formando parte de la comitiva fúnebre cruz alta, capas, incensario y dos acompañados (cap. 16, 17 y 18). La estrecha vinculación de la Hermandad con las monjas concepcionistas queda de manifiesto en las atenciones a las que se comprometía la asociación cuando moría alguna de las religiosas, pues en ese caso "ha de ser obligada la cofradía de nuestro cargo a mandar cantar una misa y tres rezadas, poniendo para ello la cera y dando a la reverenda madre abadesa cuatro pesos y cuatro reales para que con ellos sea pagado el padre capellán y demás ministros, atendiendo para esta buena correspondencia que las señoras religiosas dan a todos los hermanos difuntos su iglesia, la sepultura y un responso" (cap. 23).

Las exequias de los difuntos en el seno de la cofradía de San Sebastián imitan a las que realizaban por entonces otra cofradía de negros: "del mismo modo que se hace en la de Santa Ana", tal y como expresamente se hizo constar en sus reglas. Quizás por eso los artículos que regulan todas las atenciones con los cofrades difuntos son mucho más concisos. Se precisa, eso sí, que el lugar de entierro "ha de ser en la primera nave (de la catedral)" y que el funeral se hará con la cruz levantada, con pluvial ("llamado comúnmente capa doble") y dos acompañados. Al mismo tiempo, se establecía la obligación que todos los hermanos tenían de colaborar con los gastos del funeral, aportando un real en cada óbito, mientras que la Hermandad se comprometía, por su parte, a proporcionar seis velas, de a media libra, seis hachas, paño negro, bayetas, sotanas y derechos del cura párroco (cap.10).

Entre las actividades de las cofradías siempre ocupó un lugar destacado la celebración de sus fiestas. Las de tabla u obligatorias eran numerosísimas; ${ }^{42}$ de hecho el calendario religioso había provocado tal invasión de celebraciones que no había para cualquier buen cristiano una sola semana libre de fiestas, con la inevitable interrupción del calendario laboral y el consiguiente enojo del patrono. La situación llegó a tal extremo que la Iglesia hubo de replantearse, a fines del siglo XVII, la obligatoriedad de muchas de ellas, suprimiendo de golpe nada menos que veinticinco fiestas. En 1750 el Papa Benedicto XIV aprobaría una nueva reducción. ${ }^{43}$

42 Una relación de las fiestas "de tabla" observadas por la Audiencia de Panamá fue publicada por Fernando Muro en la Historia General de España y América, vol. XI-1. Madrid, 1989, capítulo E: "La Administración”, pág. 283.

43 Bazarte, Alicia: Las cofradías de españoles en la ciudad de México (1526-1860), Azcapotzalco, 1989, pág. 81. 
Las cofradías participaban activamente. Todas celebraban sus fiestas y adornaban sus altares. Algunas desfilaban procesionalmente en días señalados por la Iglesia: Corpus, Semana Santa (especialmente en Jueves y Viernes Santo), o bien en acontecimientos especiales e inesperados (rogativas por acontecimientos climáticos, desastres naturales, etc.). Las celebraciones propias de cada una de las hermandades, así como los días, horas y demás circunstancias, solían quedar recogidas en las reglas fundacionales para su puntual observancia.

En el mes de noviembre, en un día sin determinar, se celebraba en la iglesia de Santa Ana el aniversario general por todos los hermanos difuntos, con túmulo, misa cantada, oficio y responsos, invitándose a todos los hermanos a participar en los actos. Para esta ocasión se establece de nuevo la obligatoriedad de aportar sus limosnas, cuya cuantía tampoco se especifica. Pero la auténtica y más solemne festividad de la cofradía se celebraba en la parroquia el 26 de julio, día de su patrona Santa Ana. Se recomienda que esta celebración se haga "con la mayor pompa que le sea posible, con sermón, misa cantada y vísperas y los gastos de dicha fiesta se pagarán del arca de dicha cofradía". Además, en esta especial ocasión, se obliga a los tres mayordomos a entregar al teniente de cura, de su bolsillo, seis velas de un peso de una libra cada una y dos hachas, para mayor adorno del altar de Santa Ana.

La Hermandad de Nuestra Señora de la Concepción celebraba su fiesta principal el día de su titular, fijado no el 8 de diciembre, como cabría esperar, sino el 17 del citado mes, con sermón, misa cantada "y toda ostentación posible", obligándose a cada hermano a entregar una limosna de un peso de a ocho, así como medio real de limosna durante todos los domingos del año para colaborar en los gastos de esta celebración (cap. 6). Era entonces cuando se procedía a adornar con lujosas colgaduras la imagen de Nuestra Señora, colocada en el altar mayor de la iglesia del convento concepcionista. Seguramente eran las monjas quienes se aplicaban a esta tarea, lo que explicaría la obligación del mayordomo bolsero de la Hermandad de entregar a la madre abadesa seis pesos.

El 8 de diciembre, festividad de la Inmaculada, los sones de los "tambores portorricos" - referencia incuestionable de los orígenes africanos de los fundadores- avisaban a los hermanos de la cofradía de la celebración de una solemne misa en el convento de la Concepción, en la que todos estaban obligados a confesar y comulgar "para ganar todas las gracias e indulgencias concedidas a la hermandad" (cap. 40). De nuevo en esta ocasión los hermanos debían colaborar con sus limosnas, al igual que en las otras dos 
fiestas: la del aniversario general por los hermanos difuntos, que se celebraba en el mes de noviembre con misa y solemne procesión presidida por el estandarte de la cofradía, y la de la Candelaria. Las reglas precisaban, además, que el tercer domingo de cada mes se celebraría misa cantada en honor de la titular ante el Señor Sacramentado, con profusión de luces y música, y recogían el compromiso de gratificar a la madre abadesa con cuatro pesos y cuatro reales.

Para la Hermandad de San Sebastián existía una fiesta general de obligada asistencia para todos sus miembros: el 20 de enero, día de su patrono, se celebraba en la iglesia catedral misa solemne en la que todos los hermanos estaban obligados a confesar y comulgar para ganar las indulgencias. Además en el día citado la cofradía salía en procesión por las calles de la ciudad con la imagen de San Sebastián, cuyas andas debían portar aquellos cofrades previamente designados por el mayordomo, precedida por el estandarte de la cofradía. En esta ocasión cada cofrade contribuiría con un peso de a ocho. También la cofradía recoge en su capítulo 11 el compromiso de participar en otras procesiones públicas: "en el entierro de los cofrades, procesión del día del Corpus y su octava, en las rogativas, en la publicación de la Santa Bula y cuando hay edicto de la Inquisición”.

Una última observación conviene añadir. En las reglas de las cofradías de negros panameños no se contiene alusión alguna que permita pensar en un desfile procesional celebrado con regularidad durante su Semana Santa, como se observa en otras cofradías penitenciales, tanto peninsulares como americanas. ${ }^{44}$

\section{Los hermanos de las cofradías: número y distribución étnica}

Como ya adelantamos, el expediente que guarda las nuevas reglas de la Hermandad de Santa Ana incorpora también la relación de sus cofrades, fechada el 4 de diciembre de 1765, que a continuación pasamos a analizar. Lo primero que llama la atención del listado, que arroja un total de 414 afiliados, es el anonimato de una gran parte de sus miembros, justificado por

44 Eso no significa que no los hubiera. Otros documentos consultados demuestran que en Panamá se celebraban desfiles procesionales ya a comienzos del siglo XVII, muy similares a los de Sevilla y con la participación de cofrades negros. Todavía en el XVIII había Hermandades de penitencia, como la de San Juan de Letrán, del convento de Santo Domingo, que procesionaba el miércoles santo por las calles de la ciudad. Cuando avancemos en nuestra investigación, tal vez podamos dar una respuesta definitiva sobre estas interesantes manifestaciones de devoción popular. 
razones de orden práctico: "para no hacer la presente relación demasiado larga y tediosa", aunque no oculta su intencionalidad elitista y el espíritu de segregación que la guía: "expresaré solamente — anota el escribano Bartolomé Antonio Franco- los nombres de aquellas personas que merecen ser expresadas por razón de su carácter, y a lo último pondré el número de los demás en sus propias clases". Aquí el término "carácter" no debe ser interpretado como hoy día lo haríamos. No se trata de los rasgos peculia-

\section{GRÁFICO 1}

\section{HERMANOS DE LA COFRADÍA DE SANTA ANA (AÑO 1765)}

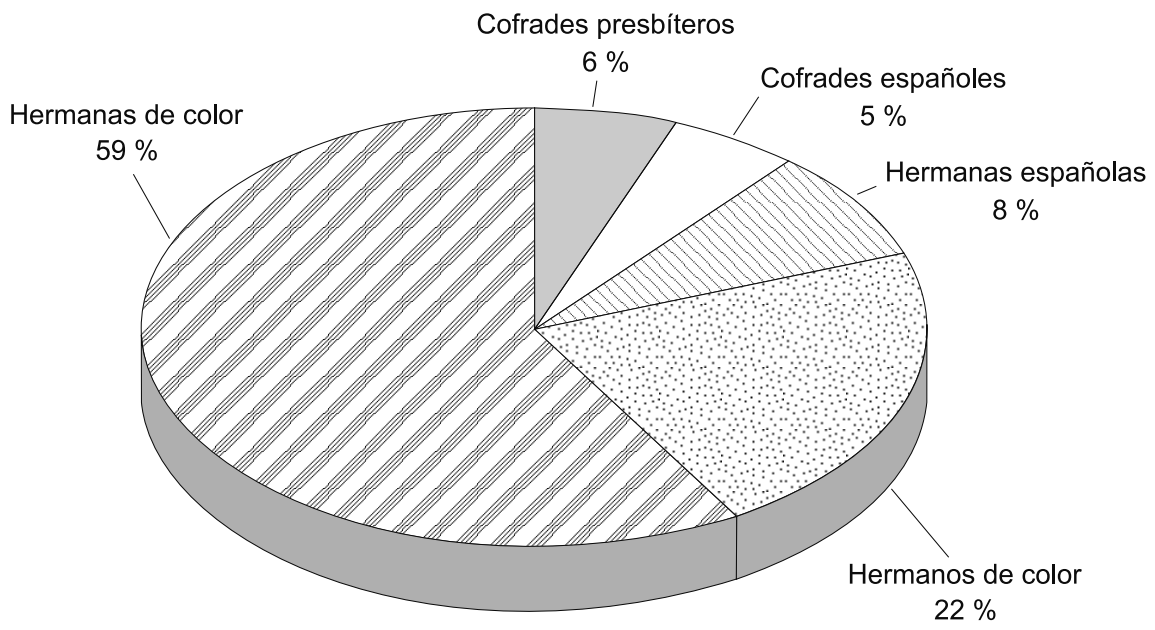

res o de la personalidad de un individuo, sino de la condición social del mismo, de manera que lo correcto sería entender que el escribano detalló solamente los nombres de aquellos cofrades más distinguidos "por razón de su estima social". A destacar el hecho de que todos los hombres o mujeres españoles, cuyos nombres se mencionan, reciben en su totalidad el tratamiento de don/doña, o excelentísima, cosa que no ocurre en el caso de los morenos. Asimismo sólo reciben el nombre de "cofrades" - tratamiento, sin duda, de distinción - los presbíteros y españoles varones, frente al resto, tanto de la gente de color como de las mujeres españolas, a los que se aplica la denominación de "hermanos"/"hermanas". Se observa, asimis- 
mo, una intencionalidad segregacionista en la división por razas o grupos étnicos ("hermanos españoles" y "hermanos llamados comúnmente de color") y por sexo (hombres y mujeres) con que se diferencia al conjunto de cofrades en las siguientes categorías:

1. Cofrades presbiteros: Suman un total de 24 y están encabezados por el obispo de Panamá, don Francisco Javier de Luna Victoria, promovido ya a la diócesis de Trujillo; por el deán de la catedral y hermano mayor de la cofradía, don José Justo López Murillo; por don José de Achurra, maestrescuela de la catedral y por don Juan José López de Goycoechea, cura párroco de la iglesia de Santa Ana. Del resto de los presbíteros, hasta los 24 que forman el grupo, se silencian sus nombres.

2. Cofrades españoles: De los 22 cofrades españoles sólo se menciona a las dos personas siguientes: don Mateo de Izaguirre, "camarero" de la cofradía "y bienhechor de la enunciada iglesia", ${ }^{45}$ y don Manuel Joaquín de Montiano (gobernador de Panamá).

3. Hermanas españolas: De las 34 que forman el total, sólo se destaca a la excelentísima señora doña Gregoria de Aguiar.

4. Hermanos llamados comúnmente de color: Forman un total de 91. Se anota sólo al mayordomo bolsero de la cofradía, el alférez José Calixto de Vega.

5. Hermanas llamadas comúnmente de color: De las 243 de esta categoría, se destaca a la mayordoma María Bernarda de San Martín.

COFRADES INSCRITOS EN SANTA ANA (RAZA Y SEXO)

\begin{tabular}{lrrr} 
& Hombres & \multicolumn{1}{c}{ Mujeres } & \multicolumn{1}{c}{ Total } \\
\hline Blancos & $46(58 \%)$ & $34(42 \%)$ & $80(19 \%)$ \\
De color & $91(27 \%)$ & $243(73 \%)$ & $334(81 \%)$ \\
TOTAL: & $137(33 \%)$ & $277(67 \%)$ & 414
\end{tabular}

Una conclusión inmediata se deriva del análisis de estos datos: la aplastante superioridad de los morenos con un $81 \%$ sobre el total. Por desgracia, los asientos no especifican la situación jurídica de los mismos y aunque sabemos de la existencia de esclavos en el seno de la cofradía, no

45 Recordemos que este comerciante vasco había reedificado la iglesia de Santa Ana. 
es posible averiguar entre los definidos genéricamente como "de color" cuantos negros esclavos y cuantos libres se incluyeron en el recuento.

Se trata de una cofradía de negros - libres o esclavos-, pero también de mujeres y especialmente de mujeres negras. Es evidente que el sexo femenino, con el 67\% del total, impera en la cofradía de Santa Ana y muy especialmente las mujeres de color - 243 hermanas de color frente a 34 hermanas blancas- con un peso porcentual sobre el total cercano al $60 \%$.

\section{GRÁFICO 2}

HERMANOS DE LA COFRADÍA DE SANTA ANA (DISTRIBUCIÓN POR RAZA)

334

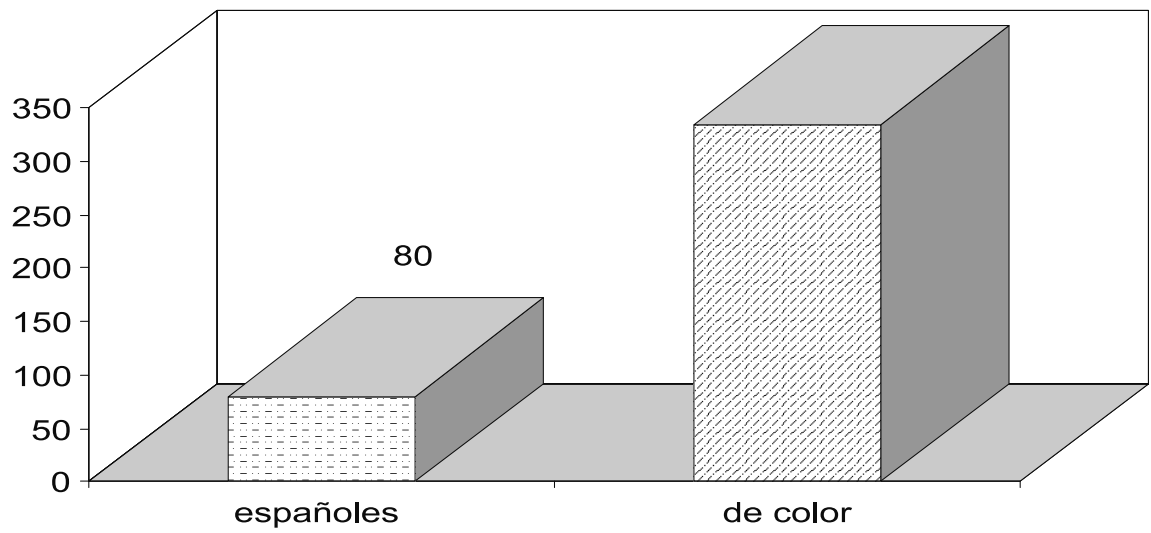

La cofradía de Santa Ana no menciona en sus reglas ningún requisito para ingresar en la hermandad. Sin embargo en el caso de las otras dos cofradías se fijan algunas normas a tener en cuenta que, a nuestro parecer, constituyen una notable manifestación de los prejuicios que guían a la sociedad jerarquizante y discriminatoria de aquella época. En la cofradía de San Sebastián podía ingresar como hermano "cualquier cristiano, sin pedir otro requisito que el que sean de ánimo quieto y de buenas costumbres, lo que deberá averiguar el mayordomo" (cap. 14). Una cláusula muy similar incorporan las reglas de La Concepción: "Ser cristianos, sin atender a las calidades", precisando del mismo modo lo siguiente: "sólo que tengan bue- 
COFRADÍAS DE NEGROS EN EL PANAMÁ COLONIAL

\section{GRÁFICO 3}

HERMANOS DE LA COFRADÍA DE SANTA ANA (DISTRIBUCIÓN POR SEXO)

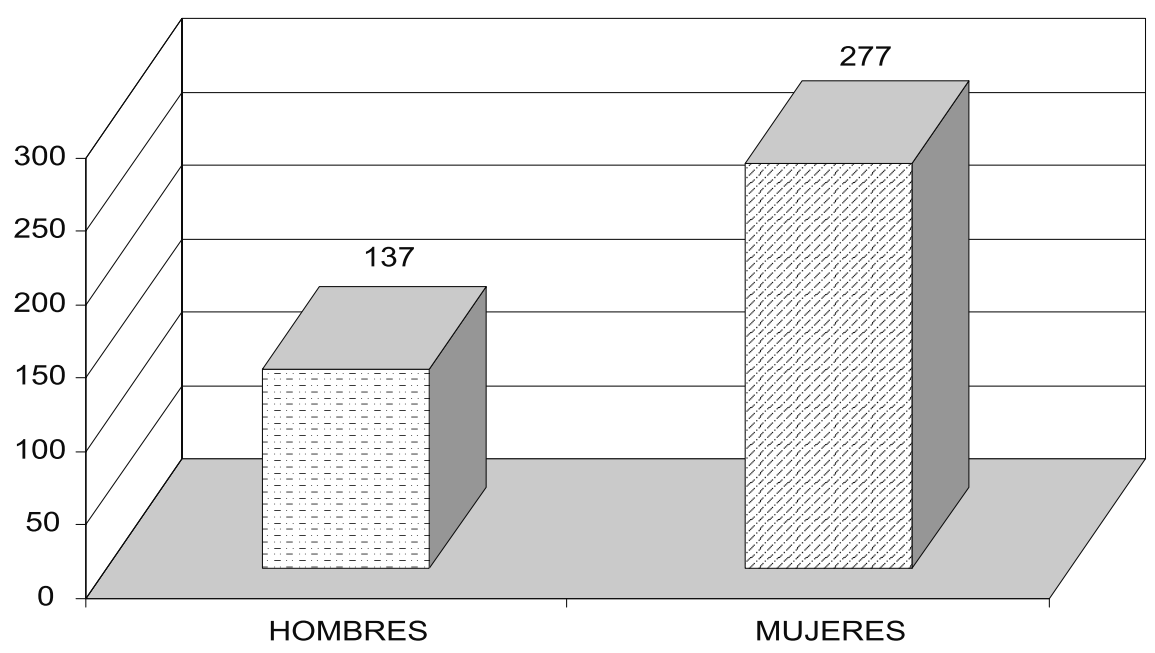

GRÁFICO 4

HERMANOS DE LA COFRADÍA DE SANTA ANA (DISTRIBUCIÓN POR SEXO Y RAZA)

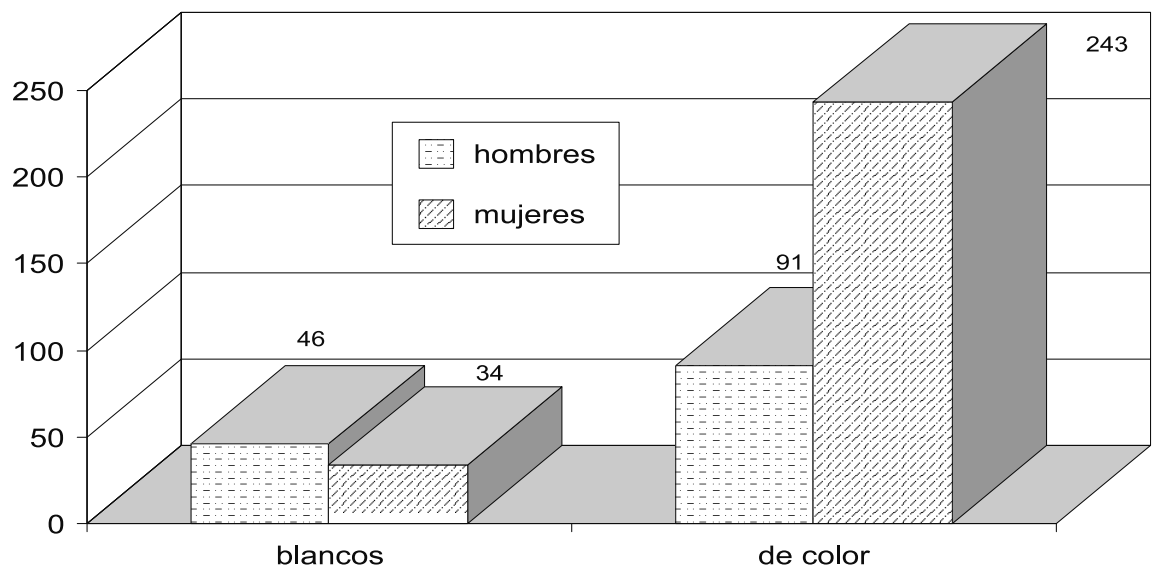


nas operaciones y costumbres, que no sean de genio revoltoso", pues en caso contrario el hermano mayor de la hermandad quedaba facultado para borrarlo del libro de asiento (cap. 26). Se consideraba un rasgo intrínseco de los africanos y mezclas su carácter alborotador, desordenado y festivo, de aquí estas precisiones. Con palabras de Carlos Aguirre, los negros libres compartían con otros grupos étnicos, genéricamente designados como "castas", un patrón de conducta que ha sido denominado como "cultura plebeya", muy distante de las exigencias de los sectores dominantes, política y socialmente temida. Y — concluye - "si algún factor distingue nítidamente a la plebe es su carácter inestable". ${ }^{46}$ Viviendo de oficios eventuales y mal pagados, conviviendo con la marginalidad y el mundo del lumpen, inmersos en conductas sociales desordenadas y con propensión a la violencia, todos los negros y morenos - incluso aquellos que consiguieron escalar posiciones destacadas dentro del artesanado o la milicia, por ejemplo- tuvieron que soportar toda la carga de desprecio y humillaciones con la que fueron considerados por las élites por su sola filiación étnica y su posición subordinada.

Observaciones como las que acabamos de ver se vierten igualmente en otras cofradías de negros peninsulares en siglos pasados. Isidoro Moreno escribe que la cofradía sevillana de Nuestra Señora de los Angeles (o de "Los Negritos") tenía establecida en sus reglas de 1554 la obligatoriedad de realizar una información secreta sobre cada nuevo solicitante, "y si es escandaloso de costumbres no sea recibido, y si después de recibido fuere de malas costumbres, como borracho, ladrón o blasfemo, que sea notorio, corríjanlo hermanablemente, y si no se enmendare a dos veces que sea corregido, sea echado de la Hermandad hasta que conste su enmienda". Esta disposición es interpretada por Moreno como una manifestación más de la dimensión ejemplarizante de la hermandad de los negros, pues considera que uno de los objetivos de la autoridad eclesiástica "fue la de poder contar con negros devotos que fuesen ejemplo y guía moral para el resto de los integrantes de su etnia". ${ }^{47}$

Una última observación conviene respecto a la admisión de nuevos hermanos. Guiada por motivos nada espirituales, la cofradía de La Concepción tenía prohibido su ingreso a los enfermos y personas "de edad avanzada", sin precisar el límite de edad, justificándose esta medida en que

46 Agentes de su propia libertad. Los esclavos de Lima y la desintegración de la esclavitud, 1821-1854, 2. ${ }^{a}$ edición, Lima, 1995, págs. 165 y ss.

47 Moreno: La antigua Hermandad..., pág. 63. 
"no se puede esperar de ellos beneficio alguno y antes sí por el contrario mucho perjuicio para la cofradía" (cap. 41). Conviene aclarar que este capítulo fue luego censurado en 1784 - a requerimiento de la autoridad gubernativa - obligando a la cofradía a introducir la siguiente frase: "podrán ser admitidos los viejos y enfermos que quisieren alistarse en ella, con tal que no adquieran derecho a los entierros, aniversarios, etc."

En la fecha citada se supeditó asimismo el placet que la Hermandad había solicitado de sus reglas nuevamente redactadas a la supresión de aquellos capítulos que imponían la obligatoriedad de entregar limosnas, lo que impedía el ingreso en la cofradía a los más necesitados y el disfrute de sus beneficios espirituales.

"Parece justo — dictaminó el asesor del gobernador de Panamá- que la aprobación que se dé sea con la circunstancia que todos los fieles que quisieren alistarse en ella sean admitidos aunque no contribuyan cosa alguna, sin podérseles obligar a ello, sino sólo aquellos que quisieren ser participantes de los entierros, aniversarios, misas, sufragios y demás actos de costo porque para este fin se exigen las cantidades que se comprenden en dichas constituciones".

Y a continuación se justificaba la medida en la siguiente premisa:

"Y siendo el principal objeto de estas piadosas fundaciones el logro de las indulgencias concedidas por los sumos pontífices, quedarían privados de ellas los pobres, que no debe permitirse porque franqueándose a los fieles graciosamente el tesoro de la Iglesia, no deben quedar por su miseria privados de él, mayormente cuando está prohibido por la Santa Sede y principalmente por nuestro Santísimo Padre Pio V, todo interés en asunto a dichas indulgencias". ${ }^{48}$

Por desgracia son pocos los datos que poseemos respecto a los hermanos de las cofradías de San Sebastián y de La Concepción, aunque en los expedientes que generaron el proceso de sanción de sus reglas constitucionales figuran los nombres de algunos de sus miembros a los que pasaremos a referirnos. En las de San Sebastián (1770) sólo se menciona a su mayordomo, Juan José Carrillo, de oficio "ayudante de la tropa de morenos". ${ }^{9}$ Las de La Concepción recogen en 1767 las firmas de 16 hermanos, de ellos cuatro maestros y un bachiller, si bien es seguro que su número debió ser mayor, puesto que — tal y como se hace constar- sólo figuran los que

48 AGI, Panamá, 291, doc. 8, págs. 29 y 30.

49 Se trata, seguramente, del mismo Juan José Carrillo que figura en 1783 en el expediente de la cofradía de La Concepción como uno de sus hermanos más antiguos. 
saben escribir. Ahora bien, dentro de este grupo se constatan las ausencias de algunos miembros de la hermandad que no estuvieron presentes en el acto por alguna razón que se nos escapa. Esta es la nómina:

\section{Relación de los cofrades de la hermandad de la Concepción asentados al pie de sus reglas constitucionales en 1767:}

Maestro Martín González Salado/ Bartolomé Señore/ Maestro Jacinto García y Guerra/ Vicente José del Río/Bachiller Santiago Rodríguez/ Maestro Manuel Gabriel de Avila/ Maestro José de la Guardia/ Andrés Pardo/ Andrés Corsino Sandino/ Valeriano Meléndez / Juan Cornelio de Echeverz/ Sebastián de Zárate/ Leoncio José Serrano/ Juan José Ruiz/ Matías José Pao/ Ignacio Maltez/Y por todos los hermanos que no saben escribir: Bartolomé Señore.

El expediente contiene anotaciones de años posteriores que revelan la presencia de otros hermanos, como Juan José Carrillo y don Javier del Bosque. El primero era capitán de las milicias de morenos en 1783, fecha en la que declara tener 60 años. El segundo desempeñaba el cargo de hermano mayor de la cofradía cuando se produjo el gran incendio de 1737 $\mathrm{y}$, en consecuencia, debió tratarse de un sacerdote. De los cofrades que figuran en la nómina arriba indicada declararon en 1783 Valeriano Meléndez, "criollo", quien por entonces contaba 70 años; Andrés Corsino Sandino, también "criollo" y de la misma edad, quien acreditó su antigüedad en el cargo pues aseguraba que cuando se produjo el incendio de 1737 - tendría entonces 24 años- ya era mayordomo de la cofradía. Y por último, Juan Cornelio de Echeverz, de 65 años, quien formaba parte, como Juan José Carrillo, de las milicias de morenos con el rango de teniente. Es bastante probable que muchos otros hermanos de ésta y de las restantes cofradías de morenos pertenecieran al ejército regular ocupando cargos de distinto rango. "A principios del siglo XVIII — escribe Omar Jaén - la mitad de las milicias de la gobernación de Panamá y Portobelo están compuestas por hombres de color, aunque de matices variados. Algunos de estos oficiales pardos, gente poderosa en sus poblados, hijos de señores destacados de la sabana, criollos casados con mulatas, terminarán hasta por adquirir el tratamiento de "don" poco tiempo después, al final de la centuria y en el siglo XIX, y ser considerados como del grupo de los blancos dominantes y entre los principales en el interior del país". ${ }^{50}$

50 La población del Istmo de Panamá..., págs. 388-389. 
Por último, queremos destacar el hecho de que muchos panameños estaban inscritos como hermanos de varias cofradías a un mismo tiempo: compartían devociones y a veces hasta cargos de responsabilidad. Tal circunstancia es más previsible, desde luego, entre los españoles que entre negros y morenos, pues la carga impositiva que exigían las hermandades, disimulada bajo el concepto de "limosna", disuadía a los sectores más humildes. Por ejemplo, nombres como los del doctor don José Andrés de Achurra, maestrescuela de la catedral de Panamá (cofrade de Santa Ana y de la Caridad), don José de la Guardia (hermano de la Caridad y de la Concepción) y Juan José Carrillo (mayordomo de la cofradía de San Sebastián en 1770 y hermano a un mismo tiempo de la de la Concepción), entre otros, aparecen registrados en fechas muy cercanas en dos hermandades a la vez. 